\title{
Theoretical Approach to Agroturism and Its Contribution to Local Development
}

\author{
Lisbet Eunice Pérez Anzardo ${ }^{1}$, Evelina Cardet Fernández ${ }^{2}$, Irina Reyes Martínez ${ }^{3}$, \\ Reynaldo Guzmán Páez \\ 1,3,4Teaching Department of the Municipal University Branch Calixto García, University of Holguín, \\ Holguín, Cuba \\ 2Teaching Department of Tourism of University of Holguín, Holguín, Cuba \\ Email: lepereza@uho.edu.cu, evelina@uho.edu.cu,ireyesm@uho.edu.cu, reynaldogp@nauta.cu
}

\section{Abstract:}

Tourism as a driver of local development. It is also an international practice with results exhibited by countries from various latitudes. Therefore, a tourist management is imposed who allows the identification of gaps in tourist competitiveness, customer satisfaction, increased income, and an improvement in the quality of the population life. Today, city dwellers appreciate the rural world as the corner where tranquility, authenticity, nature, traditions, among other riches, are treasured. This new concept of rural tourism makes it possible for the great tourist currents to seek other spaces that are not only sun and beach destinations, as well as representing an attractive alternative for tourists. The following article makes a reflection on the basis of the main concepts and trends linked to agrotourism as local development strategies in order to facilitate the correct management of this tourism modality. Hence, theoretical methods were used such as analysis and synthesis, historical-logical, systemic structural; and empirical ones such as scientific observation, interview, study of normative documents, among others. As a result, the bases were laid for the theoretical-practical deepening of the research and a group of conditions are proposed that allow rural tourism to develop as an outstanding framework of the agricultural sector, and diversify the offer so that it behaves as a decisive factor in local development. The study has been validated and presented at national and international scientific events with positive results.

Keywords:

rural tourism, agrotourism, local development

\section{Introduction}

The Sun and Beach tourism modality has been and continues being the segment of this market that contributes the largest flows of tourists on an international scale (Fayos Solá, E. 1997; Ascanio, A. 2004; Rodríguez, G. 2019; and others). However, it is distinguished from another alternative tourism development model associated with interaction, experiences, satisfaction and personal enrichment in close connection with the natural environment, popular culture and everyday life in general.

Many years ago, the field was only valued as the support of agricultural production and the work of farmers was considered important because they were in charge of producing food and other agricultural goods. The term rural tourism begins to be used when farmers realize that the product offered and their rural culture could be the key component to encourage a new tourism modality. 


\section{Economit Journal: Scientific Journal of Accountancy, Management and Finance ISSN: 2775-5827 (Online), 2775-5819 (Print)}

Vol. 1, No. 3, August 2021, Page: 165-176

Email: economitjournal@gmail.com

The continuous growth of this sector has caused a greater demand in the tourist products that are demanded and the movement of these towards alternative forms, (Bigné, E; Font, X y Andreau, L. 2000; Beltrán Vargas, L. C. y otros 2002; Bernal Ruiz, Z 2010; González Sainz, Y. 2012), in which social responsibility for the protection of the natural, historical and cultural values of the destination is prioritized with greater clarity.

During the last decades a new environmental culture has been fostered, where the growing concern for the environment has been decisive for the emergence of the tourist trend that has nature as its destination, and which consolidates the international demand for products with these characteristics; where the impulse that the most varied forms of this type of tourism have gained is notorious.

An opportunity to take advantage of is that the current tourist markets coincide with the main issuers of Nature Tourism at an international level; it demonstrates a marked interest for a segment of market to the interchange with the traditions and agricultural activities of the peasants that must be used for the governments and the community (Oe, H., \& Yamaoka, Y. 2021; Weeks, M., Oe, H., Yamaoka, Y., \& Hirata, T. 2021).

This requires the design of an offer adapted to the new needs of exchange with the environment and local cultures. The strengthening of the agrotourism modality (Ascanio, A. 2004; Partido Santanach, D. y otros 2009; Rodríguez, G. 2019), increases the demand of these markets.

In Cuba, it is sought that traditional sun and beach tourism is not the only option and that city, nature and historical-cultural tourism have a preponderant role within the market of this type, since it has the necessary potential to This and from the design of exclusive products to help this sector continue to be the engine with the greatest impact on the Cuban economy.

However, the different modalities of nature tourism are only practiced in Cuba in those places considered to be of spectacular beauty, but there has not been enough incursion into the exploitation of the natural benefits of small towns that have potential for it and where the attractions are involved. with the popular community culture.

The approach to this tourist modality has been braked for diverse causes related to perception to conceive the island as an unipolar destiny of sun and beach, the adoption of strategies of environmental inadequate handling for the development of the rural tourism and economic limitations in subjects of substructure. However, it becomes visible as a potential source of sustained revenues in the Nacional plan of economic development until the 2030.

In analysis carried out to comments in social nets and other sources of promotion and commercialization of the destiny, as well as interviews to officials of the Tourism Ministry and excecutives of the agricultural sector it permits verify that there is an increment of the expectations of the clients on the sustainable agrotourism but the offers of rural tourism are even limited and the result insufficient the acknowledgment to the agricultural and culturaltraditional activity in function of a tourist product that can significantly contribute to the recovery of the economy of the country and to the rescue of the more primitive culture result insufficient.

For all the above, it can be said that insufficient use of the potential of the natural environment and the components of traditional peasant popular culture that limit sustainable 
local development persists, in a way that encourages the protection of natural diversity and historical heritage cultural.

The objective pursued with this article of reflection, is to contribute to the management of knowledge about the subject of reference, as well as to provide the necessary information to make the local population aware of the importance of this tourist modality in the economic and social development of the localities whose fundamental line is agriculture and livestock; not only because of the income it generates directly, but also because of the effects it produces in the rest of the sectors of the economy, the generation of employment and social welfare.

For the development of the research, the use of theoretical and empirical research methods were combined, among the former, analysis and synthesis, abstraction and concretion, induction and deduction stand out. Within the empirical methods were the information gathering techniques (interviews and group work) which allowed to reach at conclusions.

The theoretical novelty of the research takes place in the conceptualisation, by means of a review of literature, of the rural sustainable tourism and its report with the local development which permits understand the form in which the involucrate agents in the development of rural sustainable tourism must interact and the practical utility is in the benefits it has from the economic, social and environmental viewpoint because as much as it keeps a tight association with the life of the community which contributes to improve the standard of living of the local population and build opportunities for groups traditionally disfavored in the rural environment, the yous, women and old men, intensifies the environmental conscience and contributes to the reinforcement of the identity and local institutionalities.

\section{Review of Literatures}

The article exposes through a cohesive, unified and coherent exposition of the different concepts analyzed and constructed as a result of the research process and the literature review the relation between agroturism and local development.

\section{Research Methods}

For the development of the research, the use of theoretical and empirical research methods was combined, among the first, analysis and synthesis, abstraction and concretion, historical-logical, systemic structural, induction and deduction stand out. Among the empirical methods are the techniques for collecting information (interviews, scientific observation, study of normative documents and group work).

\section{Discussion}

\section{Development}

\subsection{Nature Tourism}

Tourism has frequently been considered (Ayala Castro, H. y Martín Fernández, R. 1999; Ascanio, A. 2004; Rodríguez, G. 2019; and others), as a set of relationships and phenomena arising from trips and temporary stays of people who move outside the confines 
of their habitat, to develop activities related to rest and recreation; with the consequent return to their place of origin.

At the end of the 20th century, it was recognized as the most important economic activity in the world, both for its contributions to the economy and for its ability to generate jobs and for its multiplier effect on the rest of the branches.

According to the UNWTO, in 2018 tourism is the third economic activity worldwide, by the value of its exports, behind oil and the chemical products industry; generates around $10 \%$ of the global gross domestic product (GDP), produces 1 in 11 jobs and represents 30\% of the total value of exports from the services sector. In more than 60 countries, tourism is the main export economic activity. It is also the largest source of foreign exchange for a third of developing economies and for half of countries considered less developed (OMT, 2018).

For its part, nature tourism has been one of the modalities that has experienced the greatest advance and growth throughout history. This topic has been investigated and developed by dissimilar researchers around the world, from its beginnings to the present day, where its main thematic axis has become how to do it in a sustainable way, carrying out activities of enjoyment, leisure and adventure that cements a responsible mindset regarding good environmental practices.

There are multiple definitions on this modality, one of the first is who defined it as the realization of a trip to those natural areas relatively without disturbing or contaminating, with the specific purpose of studying, admiring and enjoying the panorama together with its wild plants and animals and likewise any cultural manifestation (past and present) found in them (Ceballos Lascurain, 1998).

Something similar occurs with what is stated by Cebrián (2010) and Kuper (2009), where they describe it as a model of experiences based on the enjoyment of the natural landscape and environmental awareness, which takes place in natural spaces or rural and is built around qualitative, thematic, quality, individualized and specialized values.

Similarly, OMT (2002) expresses: "Nature Tourism is all types of tourism based on nature, in which the main motivation is the observation and appreciation of nature, as well as traditional cultures."

On the basis of the ideas set out in these definitions, it can be concluded that not only are the activities that can be carried out in a natural environment included in this modality, but also that reference is made to the responsibility that must be taken into account in this practice of caring and conservation of nature.

Although the importance of sustainability in this practice is true, it is also worth mentioning and analyzing the motivations for which it is mainly carried out, as is well explained in the previous approach.

The definition adopted in Cuba, appears in the Joint Resolution MINTUR-CITMAMINAG at 1999 on Nature Tourism, and states: "All the modalities of tourism in which the motivation of the trip (or excursion), or the selection of the destination, is determined by the need to approach and enjoy nature, or its components". 
In summary, all these approaches revolve around the same criterion, that Nature Tourism is the offer of products and services that produce the interrelation and appreciation of nature by its visitors in a sustainable way and with different motivations, in all its forms.

According to the Nature Tourism Business Plan for Colombia, 2012, the following are considered by-products of Nature Tourism: Ecotourism, Adventure Tourism and Rural Tourism, as shown in table. 1. These three categories in turn are already world-renowned tourism concepts or modalities with their various interpretations and routes. Bird watching, whale watching, interpretive trails

Table 1. Nature Tourism Classification

Diving, Farm Tourism, High Mountains, whales Observation, Tourist Properties, Interpretive Paths, Birds Observation, Specializes Segments

\begin{tabular}{|l|l|l|l|}
\hline \multicolumn{1}{|c|}{ UMBRELLA PRODUCT } & \multicolumn{3}{|c|}{ NATURE TOURISM } \\
\hline Sub-products & ecotourism & Adventure tourism & Rural tourism \\
\hline Specialized segments & Watch birds & Diving & Farm tourism \\
& Watch whales & Rafting, Speleology, & Estate tourism \\
& Hiking & Mountain climbing & Ranch tourism \\
\hline
\end{tabular}

Source: Nature Tourism Business Plan for Colombia 2013

\subsection{Rural tourism and Agrotourism}

Rural Tourism (García Cuesta, J. L. 1996; Beltrán Vargas, L. C. y otros, 2002; Ascanio, A. 2004; Casals Corella, C. 2006; González, M. 2011), constitutes an activity of evident growth and projection within the tourist activity, being more and more the countries that promote it; Therefore, it is necessary to promote a tourist infrastructure to create an experience of sustainable development based on tourism, which takes advantage of the historical, natural, cultural and socioeconomic wealth of the community and its environment.

Rural Tourism is then defined as a by-product of Nature Tourism, an activity that provides tourists with a comprehensive leisure offer that responds to the motivation and interest in doing it in contact with the natural and rural environment as a means to live a unique experience. linked to the customs and traditions of the area that favors the sustainable development of the rural environment (Moral et al., 2019).

There are other definitions of Rural Tourism, which are referred to below:

(Sanagustín et al. 2018) defines it as rural tourism is characterized by development in small territories with their own identity that have an extensive offer of diffuse, nonconcentrated and small-scale accommodation and leisure activities.

Rural tourism is a type of tourist activity in which the visitor's experience is related to a wide spectrum of products generally linked to nature activities, agriculture, rural lifestyles and cultures, angling. The same as visiting places of interest (UNWTO, 2020).

Rural Tourism follows the principles of sustainable development: it seeks to take advantage of current natural resources without affecting the needs of future generations. Sustainability in tourism, as a concept, is defined as Ecotourism, Green Tourism or Responsible Tourism. Whatever its description, it is seen as a means of recognizing that the Earth has limited resources and that tourism, like other sectors, has limits to development, especially in specific places. 
Agrotourism is, as before, a specialized segment of rural tourism has been proposed, it is therefore a variant linked to the nature tourism modality that aims to satisfy certain environmentally committed market segments, with an interest focused on the knowledge of rural culture and promotes new forms of coexistence in the regional contexts of tourism based on maintaining environmentally sustainable agricultural practices (Rodríguez, G. 2019).

Agrotourism is emerging as a type of tourist activity that offers the visitor the possibility of knowing aspects of the local culture and learning about traditional practices of cultivation, harvesting and processing of agricultural, forestry and fishing products, in addition to handicrafts. There are already "tourist packages" in Latin America that offer visitors the possibility of staying, for one or several days, in farms where they not only rest and enjoy the rural landscape, but also get involved with the way of life of the producer and his family. On the other hand, Agrotourism constitutes an option for the diversification of agricultural and agro-industrial activities, with which not only the owners of these enterprises benefit, but also other rural inhabitants who, by this means, have new sources of employment and income. and additional arguments for staying in the rural spaces in which they were born and raised (Pumares, 2019).

Other authors (Osorio et al., 2015) consider that Agrotourism, from the perspective that it includes the actions of the rural, agrarian and agricultural environment; It is a form of alternative tourism whose essence can be seen in the set of activities organized by farmers as a complement to the development of their main activity, to which tourists are invited to participate and which in turn constitute services for which they are charged. This arises and is linked to the agricultural activity itself, where the organizer of the activity is the farmer himself and the heterogeneity and complexity of the real world, its specific environmental characteristics, projects, social actors and access to field resources are comprehensive. It is then that the actors involved value cultural practices, and each economic and cultural activity is recognized as part of the way of life of a certain community.

In rural tourism, the enjoyment of rural life and contact with its inhabitants is privileged, without specifically highlighting agricultural practices and Agrotourism, has as its axis of its offer the activities of rural farms, such as: harvesting, milking, rodeo, threshing, canning, assistance in feeding and caring for animals. These activities are combined with other recreational activities (walks around the farm, bird watching, horseback riding, boat rides and visits to the surroundings on foot or by cart, among others).

Both modalities provide rural experiences, complement each other and create opportunities for visitors to have direct contact with agriculture, livestock and natural areas, as well as with the culture and traditions of the community.

This practice has been considered in recent years as a strategy according to which the development of communities acquires the necessary relevance to achieve the mobilization of people towards spaces that offer them the opportunity of unique and novel experiences to be in direct contact with the environment and exchange with different cultures and customs (Parra-Cisneros-Velasteguí, 2019).

Agrotourism is still an unexploited model that can contribute to maintaining an economy based on rural and agricultural activities of small and medium-sized entrepreneurs, as well as rural landscapes, customs and local culture. This challenge goes beyond the scope of businessmen and facing it requires concerted actions between local governments and tourism managers, within a vision of the territory (Blanco \& Riveros, 2010). 


\subsection{Background of Rural Tourism and Agrotourism}

During the 19th century, especially in Switzerland and Austria, there was already a minority of country-loving travelers seeking peace, quiet, nature and authenticity. These settled in peasant houses to share their customs and cultural traditions, which in turn contributed to the home economy, since the products that were offered were those from the farm.

Rural Tourism appears for the first time on the European continent; in countries such as Spain and France that were experiencing an increase in the levels of education in society, changes in the scales of values, the appearance of new leisure needs, new demands in terms of products and services, the increase in demand itself worldwide, the saturation of traditional destinations and the incorporation of others, wanting to know new destinations, the division of vacations, have benefited tourism development in general and rural tourism in particular (OMT, 2002).

In Cuba, during the first half of the 19th century, estates and farms dedicated to the sowing of sugar cane, cattle ranches, coffee, etc were developed; that combined with their main activity the accommodation of travelers and family guests.

In the 20th century, the only experience developed with positive results in rural tourism was started in the 1990s in the province of Pinar del Río in the Las Terrazas Community, in the easternmost part of the Sierra del Rosario, belonging to the Guaniguanico mountain range, municipality of Candelaria. In this community built by the revolution, a tourist infrastructure began to be promoted to create a rural experience of sustainable development, based on tourism, to take advantage of the enriched native natural wealth, which allowed in 1994 the creation of the Tourist Complex Terraces that operate on site.

At present, there are several areas of the country where this tourism modality is promoted, but it continues to be a projection of the Ministry of Tourism to renew and expand tourism products in the Nature modalities, as well as to enhance the accommodation infrastructure, for the stay of Tourism specialized ecological.

Coupled with the interest as a country to preserve the national heritage, it works based on the commitments acquired with the UN in the context of the 2030 Agenda and the Sustainable Development Goals. Cuba, as a destination, offers a sustainable tourism product, based on the principles of hospitality, peace and security that has fascinated visitors to the archipelago who advocate sustainable tourism in harmony with the environment.

In summary, from the above it can be concluded that Rural Tourism and Agrotourism:

1. They are presented as a modality of the so-called alternative tourism.

2. Provides a direct increase in the local economy, generates employment and slows the rural exodus.

3. It is practiced in the field, transcends the agricultural and maintains strong links of exchange with the urban.

4. Allows physical and psychological balance for both tourists and individuals in the community.

5. It follows the principles of sustainable development and is considered the most humane segment of alternative tourism.

6. The Royal Spanish Academy equates both terms and defines Agrotourism as rural tourism that especially includes agricultural and livestock activities.

7. They provide rural experiences as they allow direct contact with agriculture, livestock and natural areas, as well as with the culture and traditions of the community. 


\subsection{Agrotourism and Local Development}

There are several authors (Alburquerque, 2002; Araújo N. y Paül V., 2012; Noa G. y Gascón G., 2019) who agree that local development is based on the identification and use of the endogenous resources and potential of a community.

Agrotourism, for its part, is considered a territorial development strategy for the reactivation of rural areas, giving value and hierarchy to local identity and production processes, through a commercial and tourist vision.

It agrees with Rodríguez Alonso (2019), when he states that Agrotourism is a form of alternative Tourism whose essence is appreciated in the set of activities organized by farmers as a complement to the development of their main activity, to which they are invited to to participate to tourists and which in turn constitute services for which they are charged.

Agrotourism thus represents a viable and attractive alternative as a local development strategy, the valuable natural and physical resources available can be used according to new land uses. All this implies a high degree of revaluation of the traditional activities of a territory; where different patrimonial and sociocultural values are integrated, being the rural family and the natural environment, the main protagonists (Noa G. y Gascón G. 2019).

Local development aims to place the human being and collective interests as a central point, since it enhances the capacities of individuals in their daily sphere. It is an approach and a practice that seeks to promote endogenous development, self-organization and social wellbeing, for which it requires both collective participation and individual intervention (Gascón G. 2019).

According to Gascón (2016), cited by Noa G. and Gascón G. 2019, any tourism initiative (local development tourism projects) in rural areas, based on Agrotourism, constitutes a local initiative of management and effects local. For tourism to behave as a factor of local development, the following conditions must be met:

- Local development initiatives are conceived and managed as part of the municipal strategy, fostering the greatest possible articulation and integration of the interests, needs and priorities of all the actors involved.

- It influences the progressive and sustainable transformation of the municipalities that have rural areas with tourist potential, so that from a territorial, participatory and sustainable management progress is achieved in all three dimensions.

- The development of management capacities is promoted, through the formulation and implementation of effective mechanisms for the development of tourism projects and programs based on the potential of the municipality, where the use of resources of all kinds includes improvement in employment. and in the education and training of human resources.

- The participation of all local actors becomes active and integrated, establishing alliances between public companies and private producers, as well as other forms of cooperation, such as collaboration networks.

\section{Conclusion}

After the analysis carried out on the topic addressed, common criteria could be established with the authors consulted, with the purpose of persuading both the academic community and the managers of the localities to promote rural tourism and agrotourism from 
a tourist planning that facilitates a better development to carry out a truly sustainable tourism; raising awareness among all parties involved in the impacts generated by tourism.

From the reflection carried out in this study on the concepts and tendencies of the agro-tourism as strategies of local development and on the base of the contribution so much theory as practice is demonstrated that the agrotourism as mark highest grade on an examination of the agricultural sector and as governmental politics, permits diversify the offer of the agricultural businesses, as well as a social regeneration in harmony with the environment world-wide.

Rural tourism and especially agrotourism, constitute a tourism modality in development that is gaining more and more followers in the world and for which Cuba has ample development potential since agritourism is fundamentally based on environmental, cultural and social quality. If it is not managed sustainably, it runs the risk of deteriorating or even depleting its own income-generating resource base, making it economically and socially unsustainable.

From the limitations detected in the tourist sector with report to the different modalities of alternative tourism and on the base of the constitution passed recently in the National of the Popular Power, in July 2019, defined directives, that mark the economic course of the tourist sector, such as the autonomy of the municipalities to create suitable strategies that permit achieve a local sustainable development in the rural communities where prevail a responsible and respectful conscience with the environment and the historical cultural patrimony, specially in the moments where must be avoided big concentrations of peoples because of the covid-19, which represents an opportunity to promote the community revitalización from the tourist activity.

\section{References}

Alburquerque, F. (2002). Marco conceptual y estrategias del desarrollo local. Instituto de economía y Geografía. Madrid. España

Álvarez, R., \& Espinosa, Y. (2008). Turismo y desarrollo local. Proyecto para convertir cocodrilo en un pueblo turístico sostenible en un área protegida de Isla de la juventud. Revista Cuadernos de turismo, No.22, julio-diciembre, 9- 33.

Ascanio, A. (2004) Turismo y desarrollo de la comunidad: un primer paso para rescatar la identidad cultural. Revista Pasos. Vol. 2, No.2. Universidad Simón Bolívar. Venezuela.

Ayala Castro, Héctor y Martín Fernández, Ramón; (1999). Curso internacional de verano 1996: Los desafíos del marketing turístico. Universidad de La Habana. Centro de Estudios Turísticos. La Habana. Cuba.

Barbini, B. (2002). Aporte del turismo al desarrollo local: Condicionantes y posibilidades. Turismo, 1 -22.

Basurto, E., Pennington-Gray, L. y Snyder, J. 2015. Preservación del patrimonio cultural para el desarrollo turístico. Revista Turydes: Turismo y Desarrollo, n.19 (diciembre2015). Descargado de: http://www.eumed.net/rev/turydes/19/zacazonapan.html.

Blanco, M. (2008). Guía para la elaboración del Plan de Desarrollo Turístico de un territorio. Convenio IICA Costa Rica y PRODAR (Programa de Desarrollo Agroindustrial Rural). San José, Costa Rica.

Blanco y Riveros (2010). El Agroturismo como diversificación de la actividad agropecuaria y agroindustrial. Instituto Interamericano de Cooperación para la Agricultura (IICA). Revista Estudios Agrarios. Págs. 117-125. San José, Costa Rica. 
Beltrán Vargas, Luz Cecilia; y otros (2002). Diseño y comercialización de productos turísticos. Diplomado Gestión y Desarrollo del Turismo Regional. Módulo IV. Universidad Externado de Colombia.

Bernal-Ruiz, Z. (2010). Cómo desarrollar productos turísticos competitivos. Manual para emprendedores, pequeños empresarios y responsables de la administración turística. México. Descargado de: https://www. academia.edu/25549858

Bigné, E; Font, X y Andreau, L. (2000). Marketing de destinos turísticos. Editorial ESIC. Madrid, España.

Butler, R. (1980). The Concept of Tourism Area Cycle of Evolution: Implications for Management of Resources. In: Butler, Richard (Ed.) (2006). The Tourism Life Cycle. Vol. I. Applications and Modifications. Channel View Publications. Clevendon. USA. pp. 3-12.

Casals-Corella, C., \& Corella-Varona, J. (2006, 25-27 octubre). Un viaje a través de nuestro litoral. Potencial natural de Gibara, Holguín. Paper presented at the Primer Evento Internacional sobre Biodiversidad y Turismo BIOTUR'2006, Hotel Pernik, Holguín. Cuba.

Ceballos Lascurain, H. (1998). Ecoturismo, naturaleza y desarrollo sostenible. Editorial Diana SA. México.

Cebrián, A. (2010). Bases del turismo de naturaleza en la comunidad de Murcia. Revista Papeles de Geografía. Págs. 51-83 Descargado de: http://revistas.um.es/geografia/article/view/114411

De Franco, A. (2000). ¿Por qué precisamos de un desarrollo local integrado y sostenible? Brasilia 2000.

Delegación del Mintur Holguín (2019). Informe resumen de balance anual del trabajo del turismo en 2019. Cuba

Fayos-Solá, E. (1997). El capital humano en la industria turística del siglo XXI. Editorial Educación y Formación Turística. Madrid. España.

Gaceta Oficial de la República de Cuba (10 de abril de 2019) Constitución de la República de Cuba. Periódico Granma. Descargado de: http://www.granma.cu/file/pdf/gaceta/Nueva $\% 20$ Constituci $\%$ C3\%B3n $\% 20240 \% 20$ KB-1.pdf

Galindo, S. y Hernández, M. 2013. Los Valores y la cultura como subsistemas locales para la promoción del desarrollo. En: Desarrollo Territorial y Local. Procesos de Integración, Sancti Spíritus: Ediciones Luminaria, Sancti Spíritus, Cuba.

Gómez Ceballos G, Martínez A. (2009). Alternativa para el turismo de naturaleza. Caso de estudio. Soroa. Pinar del Río. Cuba. PASOS. Revista de Turismo y Patrimonio Cultural. ISSN 1695-7121. Volumen 7. No. 2. Descargado de https://doi.org/10.25145/j.pasos.2009.07.015

González-Ferrer, J. R. (2007). Conceptualización del producto turístico: Contrapunteo entre el viaje y los bienes y servicios. Revista Investigación y Marketing. ISSN 1131-6144. No. 92. Págs. 42-29 Descargado de: http://dialnet.unirioja.es

González, M. (2011). Una propuesta para desarrollar Turismo rural en los municipios de Zacatecas, México: las rutas agro-culturales. 1 (28) ISSN: 1695-7121. Descargado de: http://www.pasosonline.org/Publicados /9111/PS0111_11.pdf

González-Sainz, Y. (2012). Propuesta de diseño del producto turístico Centro Recreativo Cultural El Molino Rojo en Gibara. Trabajo de Diploma en opción al título de Licenciada en Turismo, Universidad de Holguín. Cuba

Juárez, G. (2013). Revisión del concepto de desarrollo local desde una perspectiva territorial. Revista Líder, Vol. 23, diciembre, 9-28. 
Kuper, D. (2009). Turismo y preservación ambiental: El desarrollo turístico de Península Valdés, provincial del Chubuth. Revista de turismo y patrimonio cultural Pasos. Vol. 1. Págs. 85-97. Decargado de: http://doi.org/10.25145/j.pasos.2009.07.2007

Machado, E. - Hernández, Y. (2007). Procedimiento para el diseño de un producto turístico integrado en Cuba. Descargado de: http://www.teoriaypraxis.uqroo.mx/doctos/Numero4/htm. Universidad Central de Las Villas. Cuba

Machado, E. - Hernández, Y. (2011). Del turismo contemplativo al turismo activo. Revista Periplo Sustentable. No 15. p 111-122. Cuba

Madoery, O. (2001). El valor de la política de desarrollo local. Editorial Homo Sapiens. Rosario, Argentina.

Ministerio de Turismo-CITMA-Ministerio de la Agricultura. (1999). Resolución Conjunta No. 1-99. Cuba.

Martínez, J. 2013. La sostenibilidad en el sector turístico: del marco ambiental global al marco económico-social local. Revista Desarrollo Local Sostenible, 6 (16).

Miranda Jacome, G. (2013) ¿Qué es el Turismo rural, ¿cuáles son sus beneficios y sus características? Descargado de http://reporte.lobby.com.

Moral Moral, M., Fernández Alles, M. T., Sánchez Franco, M. J. (2019). Análisis del Turismo rural y de la sostenibilidad de los alojamientos rurales. Revista Espacios. ISSN 0798 1015. Volumen 40. No. 1.

Noa G. y Gascón G. (2019). Los productos agro-turísticos como una iniciativa de desarrollo local en Cuba. Revista Universidad \& Ciencia. Vol. 8, No. 3. Agosto-noviembre, 2019. ISSN: 2227-2690 RNPS: 2450. Descargado de: http://revistas.unica.cu/uciencia

Oe, H., \& Yamaoka, Y. (2021). An exploratory discussion of the forest bathing effect in a disruptive environment: inbound tourism and Japanese nature, Japanese Society of Travel Medicine 10-11 April 2021 Tokyo (online), Available at: https://eprints.bournemouth.ac.uk/35829/ [Accessed 15 August 2021] .

Organización de Naciones Unidas (2012). Conferencia de las Naciones Unidas sobre el Desarrollo Sostenible. UNEP, Río de Janeiro. Recuperado de: https://rio20.un.org/sites/rio20.un.org/files/a-conf.216-1-1_spanish.pdf.pdf

Organización Mundial del Turismo (2002). Previsiones mundiales y perfiles de los segmentos de mercado. Madrid. Descargado de: http://www.wto.org/ spanish/ress/statis_s/wts2010_s/wts18_toc_s.htm.

Organización Mundial del Turismo (2015). El turismo hacia el 2030. Panorama OMT del turismo internacional. Edición 2015. Recuperado de http://www.eunwto.org/doi/book/10.18111/9789284416875.

Organización Mundial del Turismo (2018). Turismo, Comercio y la OMC: Comunicado conjunto de la OMT, la OMC, el ITC y el W'TTC. Recuperado de http://www.unwto.org

Osorio, R., Espeitx, E, y Serrano, V R. (2015). Patrimonialización del queso añejo y Turismo rural en Zacazonapan, Estado de México. Revista Turydes: Turismo y Desarrollo. No. 19. http://www.eumed.net/rev/ turydes/ 19/ zacazonapan.html.

Palmas, Y., Serrano-Barquín, R., Gastón, J., Cruz, G., \& Fávila, H. (2014). Modelo teóricoMetodológico para el estudio del turismo armónico y el desarrollo local. Revista Investigaciones turísticas No.7, 23-46.

Parra Cárdenas, A. V., Cisneros Mustelier, L., Velasteguí López, E (2019). El Turismo rural y aportaciones al desarrollo de comunidades en territorios locales. Revista Explorador Digital. e-ISBN 8085-2608. Volumen 3. No. 4. Págs. 5-17. Octubre-diciembre.

Partido Comunista de Cuba (2016). Actualización de los Lineamientos de la Política Económica y Social del Partido y la Revolución para el período 2016-2021. Aprobados 
en el VII Congreso del Partido en abril del 2016 y por la Asamblea Nacional del Poder Popular en julio del 2016. La Habana, Cuba.

Partido Comunista de Cuba. (2017). Documentos del 7mo. Congreso del Partido. La Habana, Cuba: Tabloides I y II. La Habana: UEB Gráfica Empresa de Periódicos.

Partido-Santanach, D. y otros. (2009). Procedimiento para incorporar atractivos culturales a productos turísticos territoriales. Revista TuryDes. vol.2, $\mathrm{n}^{\circ} 5$. Descargado de: http://eumed.net

Perelló-Cabrera, J. L. (2001). Desarrollo y promoción de productos turísticos. Curso de Postgrado. Universidad de La Habana. Centro de Estudios Turísticos. Cuba. Descargado de: http://intranet.uclv.edu.cu/fiit/cetur/ comercialización turística.

Portillo, R. B. (2006). El turismo de naturaleza en España y su plan de impulso. Revista Estudios Turísticos. ISSN 0423-5037. No. 169-170, 2006 págs. 7-38. Descargado de: http://www.dialnet.unirioja.es

Pumares Chat, Argelia C. (2019). El Agroturismo: una opción para el Desarrollo Económico de Ich-Ek, Hopelchén, Campeche. Revista Electrónica Multidisciplinaria de Investigación y Docencia. No. 15. Diciembre 2018 - mayo 2019.

Ramírez, J.F. y Pérez, I. (2014). Manual de taxonomía y términos Turismo de naturaleza y Turismo rural. Escuela de Hotelería y Turismo. Pinar del Río.

Riveros, H y Blanco, M. 2003. El agroturismo, una alternativa para revalorizar la agroindustria rural como mecanismo de desarrollo local. Lima, PE, IICA-Prodar

Rodríguez Alonso, G. (2019). El Agroturismo, una visión desde el desarrollo sostenible. Revista Centro Agrícola. Volumen 46, No.1. Facultad de Humanidades, Universidad Central Marta Abreu de Las Villas, Carretera a Camajuaní km 5¹⁄2, Santa Clara. Cuba.

Sanagustín Fons, M. V., Lafita Cortés, T. \& Moseñe, J.A. (2018). Social Perception of Rural Tourism Impact: A Case Study. Sustainability. Descargado de http://www.researchgate.net

Secretaria de Turismo de México (SECTUR) (2002). ¿Cómo desarrollar productos competitivos? Manual para emprendedores, pequeños empresarios y responsables de la administración turística. 107 p. México.

Secretaria de Turismo de México (SECTUR 2003). Guía muestra para la identificación y diseño de productos de turismo cultural de las ciudades mexicanas Patrimonio de la Humanidad: Guanajuato, Morelia, Querétaro y Zacatecas. Secretaría de Turismo del Gobierno Federal. Primera Edición. Descargado de: https://cedocvirtual.sectur.gob.mx/janium/Documentos/99 05.pdf

Solsona, J. (2000). Gestión de la calidad en espacio turístico rural. Revista Gestión Turística. No 5. Edición Especial ISSN 0717-1811, 7-17.

Valdés-Peláez, L. P. (1996). El Turismo rural en España. Editorial Civitas. Madrid. España.

Weeks, M., Oe, H., Yamaoka, Y., \& Hirata, T. (2021). Young Businesspeople's Entrepreneurial Perceptions and Intentions to Contribute to Local Communities: A Case Study of the Cultured Pearl Industry in Mie, Japan. Economit Journal: Scientific Journal of Accountancy, Management and Finance, 1(2), 96-109.

World Tourism Organization (2020). Tourism Definitions. Descargado de http://www.eunwto.org 